\title{
Critical Thinking Development In Undergraduate Engineering Students From Freshman Through Senior Year: A 3-Cohort Longitudinal Study
}

Patricia A Ralston, Ph.D., University of Louisville, USA

Cathy L Bays, Ph.D., APRN, University of Louisville, USA

\begin{abstract}
Critical thinking is considered a necessary learning outcome for all college students and essential for academic and career success. There are many challenges to developing a comprehensive approach to teaching and assessing critical thinking skills. Although the literature has many examples of the incorporation of critical thinking and assessment into courses, longitudinal studies following engineering students through their undergraduate career are lacking. This study assessed the impact of using the Paul-Elder Critical Thinking Framework to enhance undergraduate students' critical thinking skills with the hypothesis: There will be a significant increase in undergraduate students' critical thinking abilities from the freshman to the senior year with the explicit and strategic incorporation of critical thinking assignments. The research question was, "How do the critical thinking skills of undergraduate engineering students change as they progress through the engineering program with the explicit and strategic incorporation of critical thinking assignments?" The study was a descriptive, longitudinal study of three engineering student cohorts as they progressed through the four year undergraduate program. The study was approved by the university's Institutional Review Board. There was a statistically significant increase in critical thinking scores over the four years for each of the three cohorts. Integrating and evaluating critical thinking assignments into engineering curricula is possible, but a major challenge to critical thinking assessment using a holistic rubric is training engineering faculty in their use. The results are encouraging, and participating faculty agree; but sustaining these efforts to imbed critical thinking assignments throughout the engineering college curriculum will require effort and administrative support.
\end{abstract}

Keywords: Critical Thinking Assessment; Paul-Elder Critical Thinking Framework; Longitudinal Cohort Group Study; Undergraduate Engineering

\section{INTRODUCTION}

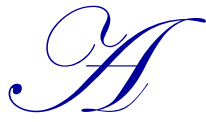

longitudinal study to enhance the critical thinking skills of their undergraduate students was undertaken at the school of engineering at a large, urban research university. The study was based on three student cohorts as they progressed through the four year undergraduate program. Initial results from the first cohort have been reported previously (Ralston \& Bays, 2013). Included in this article are: background for the study, supporting literature on critical thinking and on the Paul-Elder framework (Paul \& Elder, 2009) as the vehicle to teach critical thinking, summary of the development of the overall study including the creation of a holistic rubric aligned with the Paul-Elder critical thinking framework for use with undergraduate engineering students, discussion of the faculty training required for both teaching the framework and rating the written artifacts, and discussion of the results from the assessment of students' critical thinking skills over the entire study period. 


\section{BACKGROUND}

In 2007, the university began implementing a multi-year Quality Enhancement Plan to enhance undergraduate students' critical thinking skills in all undergraduate programs across the entire undergraduate experience as part of the regional reaccreditation process. For the reaccreditation plan, the university selected Scriven and Paul's (1987) definition that critical thinking "is the intellectually disciplined process of actively and skillfully conceptualizing, applying, analyzing, synthesizing, and/or evaluating information gathered from, or generated by, observation, experience, reflection, reasoning, or communication, as a guide to belief and action." A primary goal early in the initiative was to identify a critical thinking framework that could be used across the undergraduate programs for consistency in terminology and assessment. Frameworks and models reviewed for the initiative included: (Bloom, 1956), (Bogo \& Vayda, 1998), (Brookfield, 1987), (Facione \& Facione, 1998), and (Paul \& Elder, 2001, 2009). The models were reviewed for their comprehensiveness, applicability to all undergraduate programs, inclusion of specific cognitive skills (e.g., metacognition), and availability of high quality resources. Faculty, administrators and staff responsible for leading the initiative unanimously agreed to select the Paul-Elder critical thinking framework (Paul \& Elder, 2009) to provide intentional and consistent language across undergraduate programs because of the framework's comprehensiveness, discipline neutral terminology and extensive high quality resources.

The Engineering School embraced the comprehensive inclusion of critical thinking assessment because engineering faculty felt, and research supports that critical thinking is foundational to engineering education and to engineering practice (Mattingly, Weatherton, Druzic, Frost, \& Rahman, 2014; Alfrey \& Cooney, 2009; Rogers, 2006). However, faculty responses also indicated that critical thinking was not being included as an explicit component in preparation and implementation in most course lectures and syllabi. Faculty members typically assumed that students could learn to think critically by watching them demonstrate critical thinking as they worked problems or discussed design issues. After more in-depth discussions, most faculty members agreed that they never explicitly discussed the thought processes behind problem investigation, analysis of situations, synthesis of designs, and evaluation of alternatives. As a result, the Engineering School embraced the Paul-Elder Framework as a means of introducing common labels and descriptions for all discussions of critical thinking and developed a program to inculcate critical thinking, overtly and intentionally throughout the undergraduate curriculum, culminating with the engineering capstone design experiences. Of the approximately 90 faculty members, 25-30 were actively engaged in this longitudinal study each year. A key challenge is continuing this effort and maintaining a focus on integration of critical thinking throughout the curriculum now the study has concluded.

Although not mentioned explicitly in the Accreditation Board for Engineering and Technology (ABET) outcomes, one thoroughly versed in the Paul-Elder framework could argue that critical thinking is actually the foundation for all of the eleven program outcomes assessed for accreditation. Engineering programs must demonstrate that their students attain: (a) an ability to apply knowledge of mathematics, science, and engineering, (b) an ability to design and conduct experiments, as well as to analyze and interpret data,(c) an ability to design a system, component, or process to meet desired needs within realistic constraints such as economic, environmental, social, political, ethical, health and safety, manufacturability, and sustainability, (d) an ability to function on multidisciplinary teams, (e) an ability to identify, formulate, and solve engineering problems, (f) an understanding of professional and ethical responsibility, (g) an ability to communicate effectively, (h) the broad education necessary to understand the impact of engineering solutions in a global, economic, environmental, and societal context, (i) a recognition of the need for, and an ability to engage in life-long learning, (j) a knowledge of contemporary issues, (k) an ability to use the techniques, skills, and modern engineering tools necessary for engineering practice (ABET, 2013). All outcomes require "the intellectually disciplined process of actively and skillfully conceptualizing, applying, analyzing, synthesizing, and/or evaluating information gathered from, or generated by, observation, experience, reflection, reasoning, or communication, as a guide to belief or action", i.e. critical thinking (Scriven \& Paul, 1987). Many engineering educators believe life-long learning involves critical thinking, including (Shuman, Besterfield-Sacre, \& McGourty, 2005) and (Jiusto \& DiBiasio, 2006). The assessment of critical thinking complements the assessment of ABET outcomes for engineering programs. The better thinkers students are, the better equipped students are to achieve the outcomes. Students must be able to think critically as individuals and as members of teams. The assessment of program outcomes for engineering schools will be enhanced by strong, wellassessed critical thinking programs. 
Assessment of critical thinking in general is difficult and there is not a consensus on how to measure it $(\mathrm{Ku}$, 2009), (Liu, Frankel, \& Roohr, 2014). One study (Renaud \& Murray, 2008) suggested that improvement in critical thinking skills are more clearly detected with items focusing on specific course content rather than on general content. Although program assessment of critical thinking has been undertaken in other fields (Bensley \& Murtagh, 2012; Cavaliere \& Mayer, 2012; McKitrick \& Barnes, 2012), the only published discussion of program assessment of critical thinking for engineering was the recent work by Eppes and colleagues (Eppes, Milanovic, \& Sweitzer, 2012). Their work presents an assessment framework for five liberal education outcomes, including critical thinking, in the University of Hartford's engineering and technology programs, but gives results from only a pilot study involving a single capstone design course. This work offers an example of comprehensive inclusion and assessment of critical thinking throughout the undergraduate engineering program using specific course content.

\section{FRAMEWORK AND SUPPORTING LITERATURE}

Since 1993, 167 articles in the Journal for Engineering Education have mentioned critical thinking, and 249 papers in the 2014 National ASEE Conference included the words, clearly indicating recognition of a growing interest in developing this ability in students. NSF has supported the development of instruments to assess students' critical thinking skills and many faculty in all disciplines regard critical thinking as the most important outcome of an undergraduate education, (Stein \& Haynes, 2011). In a 2011 survey conducted by the Association for American Colleges and Universities (AAC\&U,2011), 95\% of the chief academic officers from 433 institutions rated critical thinking as one of the most important intellectual skills for their students, and $81 \%$ of the employers surveyed wanted colleges to place a stronger emphasis on critical thinking. More recently, $93 \%$ of 318 employers surveyed agreed that, "a candidate's demonstrated capacity to think critically, communicate clearly, and solve complex problems is more important than their undergraduate major," (Hart Research Survey, 2013). Although in at least one survey, employers perceived engineering graduates to be particularly poor at critical and independent thinking (Nielson, 2000).

The term "critical thinking" is familiar to most engineering educators, but it is difficult to define easily. In one study, (Paul, Elder, \& Bartell, T, 1996) it was found that $89 \%$ of teachers interviewed claimed critical thinking to be an important education objective, but only $19 \%$ were able to give a clear explanation of critical thinking. Ennis (1962) defined critical thinking as: "Critical thinking is reasonable, reflective thinking that is focused on deciding what to believe or do." Scriven and Paul (1987) gave a more detailed definition: "Critical thinking is the intellectually disciplined process of actively and skillfully conceptualizing, applying, analyzing, synthesizing, and/or evaluating information gathered from, or generated by, observation, experience, reflection, reasoning, or communication, as a guide to belief or action." Halpern in her 2003 book described critical thinking as "the thinking that is purposeful, reasoned and goal directed - the kind of thinking involved in solving problems, formulating inferences, calculating likelihoods, and making decisions, when the thinker is using skills that are thoughtful and effective for the particular context and type of thinking task". Despite a wide variety of definitions, three key elements of critical thinking are reason, reflection, and judgment. Fundamentally, critical thinking is thinking about thinking, a meta-cognitive process. The combination of reflection and reason leads to the final element, belief in the validity of a premise, process or solution to a problem, which also can lead to action. Critical thinking develops conclusions by deducing or inferring answers to questions and then reflecting on the quality of the reasoning; the end result is action, based on those conclusions.

Bailin and colleagues (Bailin, Case, Coombs \& Daniels, 1999) point out that much literature at that time characterized critical thinking simply as one or more skills, mental processes, or sets of procedures and that this characterization led to the view that critical thinking could be taught simply by practicing or demonstrating it. They point out that critical thinking must be characterized in terms of specific performance criteria, that critical judgment is developed through applying knowledge in many contexts, and that improvement is made with frequent feedback and evaluation with respect to the quality of thinking demonstrated. The development of quality reasoning cannot be learned just by drill and practice in specific content areas, but requires opportunities for reflection and feedback as more involved thinking is required in a variety of contexts. Using critical thinking, or even demonstrating critical thinking, is not the same as teaching students to think critically. A common vocabulary and conceptual constructs on critical thinking can help address the challenges of teaching critical thinking. 
The Paul-Elder framework of critical thinking (Paul \& Elder, 2008) chosen for this study has a formal structure and is a discipline-neutral schema (shown in Figure 1). It also addresses the concerns of Bailin and colleagues (Bailin, Case, Coombs \& Daniels, 1999). The framework depicts critical thinking by applying Universal Intellectual Standards to the evaluation of typical Elements of Thought, with the goal of developing certain Essential Intellectual Traits in the thinker. The framework allows for the analysis and evaluation of thought, but more importantly, it provides a common vocabulary for those who want to discuss, evaluate, or teach critical thinking. The framework has been discussed specifically in light of engineering education (Paul et al., 2006). The operational focus in the framework is the eight Elements of Thought which clarifies the building blocks of thinking; these building blocks are used by anyone who examines, analyzes, and reflects on intellectual work. These elements are embodied in eight categories of questions crucial to critical thinking: What is the purpose? (of the exercise, discussion or argument), What is the point of view? (of each participant, group or entity), What are the assumptions? (inherent premises of the argument), What are the implications? (of the reasoning or assumptions), What information is missing and needed to reach a conclusion? What inferences are being made? What is the most fundamental concept put forward by participants?, and What is the specific question that is being answered? The Universal Intellectual Standards are the criteria used to evaluate the quality of the thinking. According to the framework, applying the standards to the elements is what transforms common/general/everyday thinking to critical thinking.

Figure 1. The Paul-Elder Critical Thinking Framework

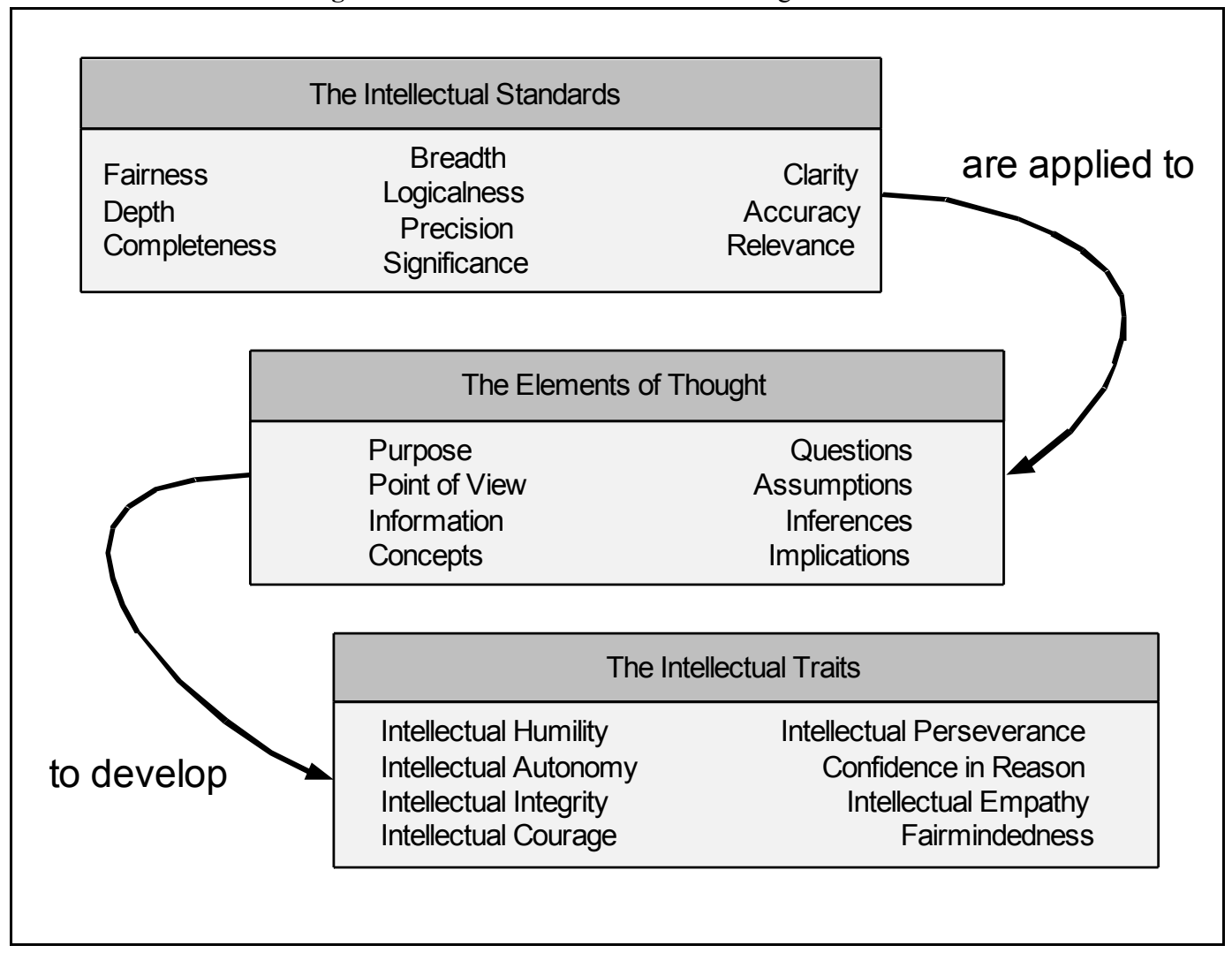

Cooney et al. (2008) found a disturbing dissonance between the degree to which engineering and technology faculty at IUPUI believed they were incorporating critical thinking experiences in their courses, and the amount of critical thinking experience students perceived they were receiving. Analysis of faculty anecdotes and examples of teaching and learning indicated to Cooney and colleagues that a clear disconnect existed between what teachers considered critical thinking experience and what students identified as exercises in critical thinking. Cooney and colleagues reviewed research on developing critical thinking skills in engineering and technology students, and identified two significant activities that could be incorporated into classes easily and were very effective: writing 
based on reflection and learning through solving problems. In any type of writing activity, students digest given information, analyze the content critically, analyze the reasoning incorporated in the information, think about their own thinking, and then articulate their thoughts and/or value judgments. One method to implement such writing for reflection is to provide rubrics for evaluating open-ended problems, and then to provide feedback to help students revise their initial written reflections. The feedback is an important step in refining thinking and cognition. Other research evaluating critical thinking using writing exercises in engineering education can be found in (Lunt \& Helps, 2001), (Gurmen, Lucas, Malmgren, \& Folger, 2003) and (Damron \& High, 2008). "Critical thinking skills allow students to more quickly assimilate subject-specific course content and also provide a framework that allows students to engage and respond to less-well defined problems", (Tsui, 2000, 2002). Tsui's research from four undergraduate institutions indicated that not only did writing assignments that required students to demonstrate a synthesis of material, evaluate arguments, and deduce conclusions improve critical thinking skills, but "re-writing" was even better due to the direct inclusion of feedback.

Problem solving is the quintessence of engineering, and learning through solving problems has been recognized for many years as a primary way to teach critical thinking (Bailey, 1979). Tsui (1998) reviewed studies of how critical thinking has been taught and found that problem solving is especially effective. Engineering faculty have focused on developing critical thinking based on problem solving, especially since the adoption of the ABET 2000 criteria (Mani, Omidvar, \& Knott, 2003), (Lombardo, 2004), and (Papadopoulos, Rahman, \& Bostwick, 2006). Recently, ethics issues and critical thinking were intertwined in a problem-based learning case-study (Chang \& Wang, 2011).

Other research related to the development of critical thinking in engineering involves ethical decision making (Wolverton \& Wolverton, 2003), (Swalie \& Kreppel, 2001), conducting experiments, (Bruno \& Anderson, 2005), assessing the social impact of technology (Nelson, 2001), using the backward design process to modify courses to emphasize critical thinking (Sgro \& Freeman, 2008), and more recently the integration of information literacy training with problem solving in engineering assignments to enhance critical thinking (Lai \& Loon, 2014) .

Challenges remain with incorporating critical thinking into engineering curricula and assessing the impact (Douglas, 2012) and (Bumbaco \& Douglas, 2014), and it is not confined to the United States (Ahern, O'Connor, McRuairc, McNamara \& O'Donnell, 2012). Ahern and colleagues challenged European engineering educators to engage more closely with educational literature to understand critical thinking and to explicitly address it in coursework. Claris and Riley (2012) challenged the current state of critical thinking teaching in engineering and developed "a reflexive view of critical thinking, leading to critical thinking not only within but also about engineering." They found "that thinking critically about engineering can challenge power/knowledge relationships, critique engineering epistemologies, engage in reflective and reflexive practice, and work relationally for social justice." Despite the challenges, educators agree that higher education needs to foster critical thinking deliberately and embrace it as a core value (Flores, Matkin, Burbach, Quinn, \& Harding, 2012).

\section{METHODS}

The Engineering School embraced the Paul-Elder Framework as a means of introducing common labels and descriptions for all discussions of critical thinking and developed a program to inculcate critical thinking, overtly and intentionally, that extends from outreach programs to elementary and middle schools, throughout the undergraduate curriculum, to the culminating experience in engineering capstone design courses. In fall 2008, faculty at the Engineering School began a four-year educational research study to incorporate the Paul-Elder critical thinking framework intentionally and transparently, across the undergraduate engineering curriculum; they also developed a plan for assessing results of the program. The program operated as an ongoing feedback loop (assessment, revision, implementation, assessment, etc.) for evaluation of critical thinking skills, much as the ongoing Accreditation Board for Engineering and Technology (ABET) assessments function for engineering program curricula.

The purpose of this study was to assess the development of critical thinking skills in undergraduate engineering students. The research question was, "How do the critical thinking skills of undergraduate engineering students change as they progress through the engineering program with the explicit and strategic incorporation of 
critical thinking assignments?" The research hypothesis was, "There will be a significant increase in undergraduate students' critical thinking abilities from the freshman to the senior year with the explicit and strategic incorporation of critical thinking assignments." The study was a descriptive, longitudinal study of three engineering student cohorts as they progressed through the four year undergraduate program. The study was approved by the university's Institutional Review Board.

\section{PARTICIPANTS/SUBJECTS}

Undergraduate engineering students were eligible to participate in the study if they were at least 18 years of age as freshmen and would complete the undergraduate engineering program in four years. A convenience sample of 649 undergraduate engineering freshmen students, across the three study years, consented to participate in the study ( $57 \%$ consent rate). From the original consented sample, 182 students ( $28 \%$ of those who consented) completed the undergraduate engineering program in four years and are the unit of analysis for the longitudinal study. The greatest decrease in the study sample occurred from the freshman to sophomore year. This initial decrease was primarily due to first year attrition since students often transfer to other majors their first year. From the sophomore to the senior year, $75 \%$ of the consented students completed the undergraduate engineering program in four years. The continued decrease in sample size was primarily due to students changing majors within engineering failing to stay in the regular sequence of program courses due to dropping courses, not taking a full load, or other reasons. The demographics for each cohort are reported in Table 1. There was no statistically significant difference in high school GPA or ACT composite score across the 3 cohorts.

Table 1. Demographics for the Three Study Cohorts

\begin{tabular}{|c|c|c|c|}
\hline & $\begin{array}{c}\text { Cohort } 1 \\
(n=50)\end{array}$ & $\begin{array}{c}\text { Cohort } 2 \\
(n=62)\end{array}$ & $\begin{array}{c}\text { Cohort } 3 \\
(n=70)\end{array}$ \\
\hline High School GPA Mean (SD) & $\begin{array}{l}3.85 \\
(.170)\end{array}$ & $\begin{array}{l}3.83 \\
(.222)\end{array}$ & $\begin{array}{l}3.89 \\
(.220)\end{array}$ \\
\hline ACT Composite Mean (SD) & $\begin{array}{l}29.36 \\
(2.317)\end{array}$ & $\begin{array}{l}29.36 \\
(3.188)\end{array}$ & $\begin{array}{l}29.82 \\
(2.270)\end{array}$ \\
\hline \multicolumn{4}{|l|}{ Gender } \\
\hline Male & 40 & 53 & 55 \\
\hline Female & 10 & 9 & 15 \\
\hline \multicolumn{4}{|l|}{ Ethnicity } \\
\hline White & 45 & 49 & 61 \\
\hline Black & 0 & 2 & 0 \\
\hline Hispanic & 0 & 1 & 2 \\
\hline Asian & 2 & 9 & 1 \\
\hline Other & 3 & 1 & 6 \\
\hline
\end{tabular}

\section{DATA COLLECTION}

The study started with a core group of committed faculty who recognized that although most all engineering courses required students to think critically, faculty were not specifically teaching students how to do so. Faculty typically "demonstrated" critical thinking as they solved problems or discussed ethical or technical issues, rather than explicitly using a common language and framework to thoroughly discuss the "analyze and evaluate" process of critical thinking so clearly articulated in (Nosich, 2012). Engineering faculty developed or revised a critical thinking assignment for a selected course in each year of the undergraduate program. The assignments were authentic assessments embedded within the courses as part of the grading requirements and direct assessments of the students' critical thinking abilities for course specific content. Student responses to the assignments (artifacts) were copied before grading, all identifying information was removed, and a unique study number was placed on the artifacts for tracking across the four-year study time period. Several faculty members in every department embraced the project to the extent that we are convinced every student was thoroughly exposed to the Paul-Elder critical thinking framework in at least one course per year. 
The specific critical thinking assignment for a required course each year that all engineering students took was:

Freshman: In the "Introduction to Engineering" course, a case-study was used to introduce various aspects of engineering before the Paul-Elder critical thinking framework was intentionally discussed in the course. A written summary of the case study served as the baseline or "pre" assessment. Details of the longitudinal study development analysis of the freshman course artifacts (baseline and course critical thinking assignments) and associated faculty scoring sessions for all three cohorts can be found in (Ralston, Larson, \& Bays,2011).

Sophomore: The "Differential Equations" course's artifact was a one page assignment that required students to answer the question "Of the many methods for solving differential equations covered in this course, if you had time to teach only one method to someone, which method would you pick and why?" Faculty reviewed the Paul-Elder critical thinking framework in class before this assignment was submitted.

Junior: The artifact collected from third year students was their cooperative internship report summary which asked students to critically reflect on their primary responsibilities. The cooperative internship seminar classes spent time formally reviewing the Paul-Elder critical thinking framework, as well as modeling for students how critical thinking skills could be used in interviewing and in engineering practice.

Senior: Artifacts from required fourth year courses from the seven degree-granting departments were written summaries from either capstone design projects or other individual assignments requiring critical analysis. In the fourth year, some faculty teaching courses where artifacts were collected made overt efforts to teach the Paul-Elder critical thinking framework, and others simply provided review materials.

\section{HOLISTIC CRITICAL THINKING RUBRIC}

Although critical thinking and assessment of critical thinking using rubrics have been discussed in the engineering education literature (Berge \&Flora, 2010; Golter, Van Wie, Brown, Thiessen, Yurt, \& Abdul, 2009; Ralston \& Bays, 2010), the studies have primarily related to a single course, not complete curriculum redesign and assessment. No existing critical thinking rubric was found that incorporated the Paul-Elder critical thinking framework for engineering. The engineering faculty decided to construct a four-point, holistic critical thinking rubric based on the Paul-Elder critical thinking framework for use with the research project (Ralston \& Bays, 2010). Figure 2 presents the engineering holistic critical thinking rubric. 
Figure 2. Holistic Critical Thinking Rubric

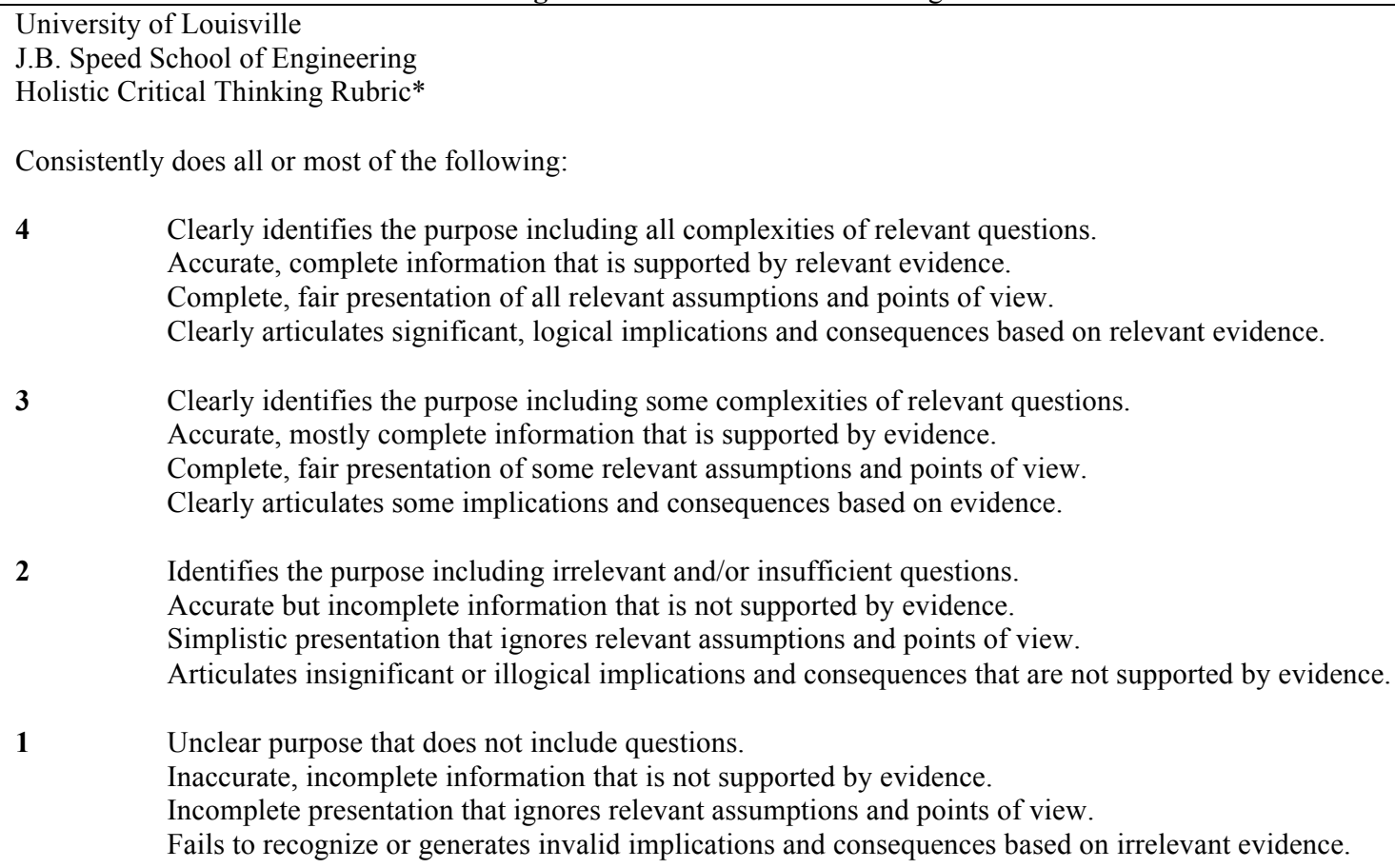

*Based on the Paul-Elder critical thinking framework

A total of 20 engineering faculty volunteered to score the student artifacts throughout the research project. Faculty received a stipend to spend on any academic expense as a compensation for the time the scoring session would take over the multi-year length of the research project. Engineering faculty were trained to score the blinded artifacts using the holistic critical thinking rubric. At least two faculty independently scored each artifact. Each faculty rater was given a file with the blinded student artifacts, assignment description, critical thinking rubric, and a form to record their scores. If there was greater than a one point discrepancy between the two faculty rater scores, a third faculty scored the artifact. Final critical thinking scores for each artifact were determined by averaging the two or three blinded, independent faculty rater scores. The procedure for scoring the engineering student artifacts was similar to the procedure for scoring university-wide outcomes. The intraclass correlation coefficient (ICC) was used to assess the consistency of the paired faculty rater scores across the study assessment periods. The average ICC increased from 0.377 in the first session to 0.428 in the final session. The number of artifacts that necessitated a third rater decreased over time from $20 \%$ in the first session to $5 \%$ in the final session. Different faculty pairs rated the artifacts in the first and final sessions.

\section{FINDINGS}

Table 2 presents the means and standard deviations for the artifact analyzed from each cohort. Figure 3 graphically illustrates the mean scores for the artifact analyzed from each cohort.

Table 2. Cohort Critical Thinking Artifact Means and Standard Deviations

\begin{tabular}{lccc}
\hline & $\begin{array}{c}\text { Cohort 1 } \\
(\mathbf{n = 5 0 )}\end{array}$ & $\begin{array}{c}\text { Cohort 2 } \\
(\mathbf{n = 6 2 )}\end{array}$ & $\begin{array}{c}\text { Cohort 3 } \\
(\mathbf{n}=\mathbf{7 0})\end{array}$ \\
\hline Freshman & $2.6434(.71045)$ & $2.3871(.63142)$ & $2.4000(.59952)$ \\
Sophomore & $2.6563(.58860)$ & $2.3846(.59945)$ & $2.3620(.59048)$ \\
Junior & $2.8370(.57898)$ & $2.9781(.59432)$ & $2.8833(.68061)$ \\
Senior & $3.1367(.63504)$ & $2.9437(.65337)$ & $2.9596(.67292)$ \\
\hline
\end{tabular}


Figure 3. Cohort Critical Thinking Artifact Mean Scores

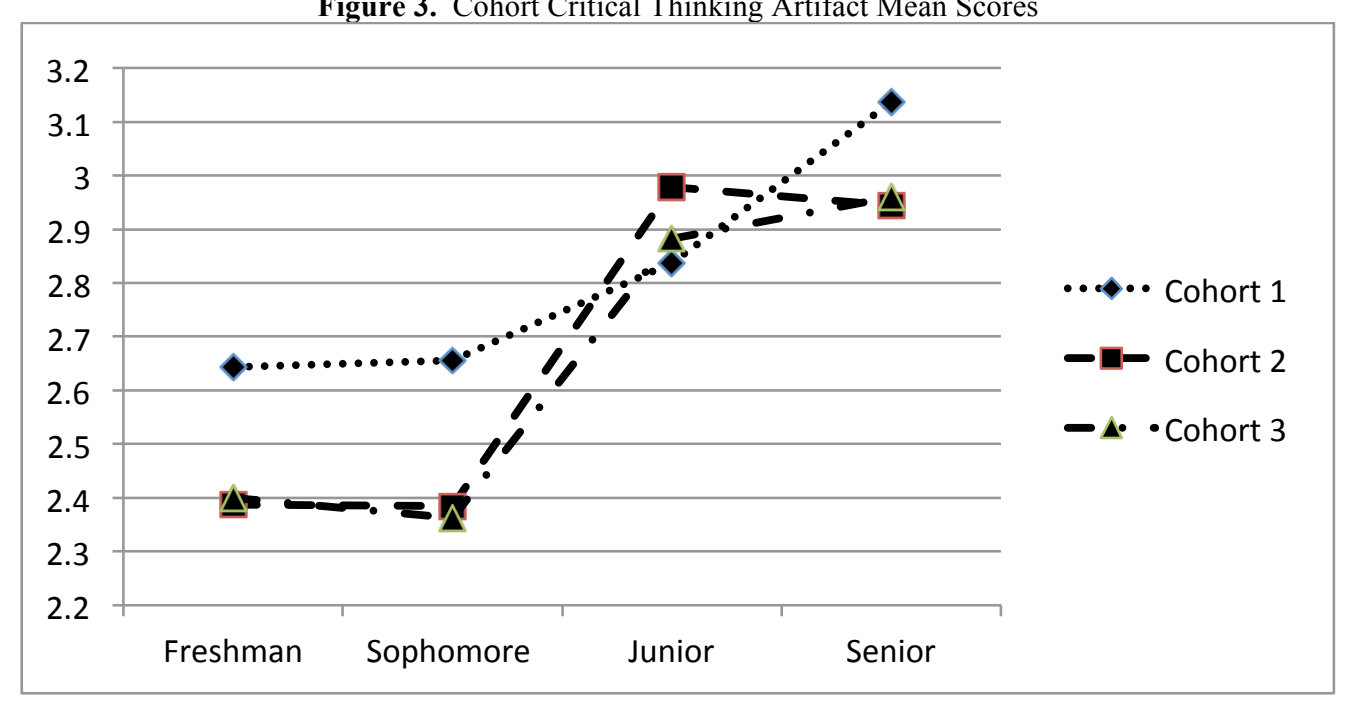

The freshman, sophomore and senior means for cohort 1 were higher than those for cohort 2 and 3 . The freshman, sophomore, junior and senior means for cohort 2 and cohort 3 were similar in value and trajectory. The sophomore artifact average score was significantly $(\mathrm{p}<.05)$ higher for cohort 1 when compared to cohort 2 and cohort 3. There was no statistically significant difference $(p>.05)$ between the three cohort groups for any of the remaining artifact average scores.

A repeated measures ANOVA was used to assess the change in subject's critical thinking scores over time. The assumption of sphericity, relatively equal variances, was evidenced by Mauchly's Test of Sphericity so no corrections were applied to the F-ratio computations. Table 3 presents the sphericity calculations for each cohort.

Table 3. Cohort Sphericity for Repeated Measures ANOVA

\begin{tabular}{lccc}
\hline & $\begin{array}{c}\text { Cohort 1 } \\
(\mathbf{n = 5 0 )}\end{array}$ & $\begin{array}{c}\text { Cohort 2 } \\
(\mathbf{n = 6 2})\end{array}$ & $\begin{array}{c}\text { Cohort 3 } \\
(\mathbf{n = 7 0 )}\end{array}$ \\
\hline Mauchly's W & .893 & .935 & .940 \\
Chi-Square (df) & $4.715(5)$ & $3.9969(5)$ & $4.155(5)$ \\
Significance & .452 & .554 & .527 \\
\hline
\end{tabular}

There was a statistically significant increase in critical thinking scores over the four years. Table 4 contains the repeated measures ANOVA for the three cohorts.

Table 4. Repeated Measures ANOVA for the Three Cohorts

\begin{tabular}{lccc}
\hline & $\begin{array}{c}\text { Cohort 1 } \\
(\mathbf{n = 5 0 )}\end{array}$ & $\begin{array}{c}\text { Cohort 2 } \\
(\mathbf{n = 6 2})\end{array}$ & $\begin{array}{c}\text { Cohort 3 } \\
(\mathbf{n = 7 0 )}\end{array}$ \\
\hline Sum of Squares & 8.616 & 20.247 & 20.699 \\
Mean Squares & 2.872 & 6.749 & 6.90 \\
F (df) & $6.693(3)$ & $20.254(3)$ & $20.611(3)$ \\
Significance & .000 & .000 & .000 \\
\hline
\end{tabular}

Specifically, the critical thinking score for the senior artifact was significantly higher than the freshman ( $\mathrm{p}$ $<.05)$ and the sophomore $(\mathrm{p}<.05)$ critical thinking scores for all three cohorts. The critical thinking score for the junior artifact was significantly higher than the freshman $(\mathrm{p}<.05)$ and the sophomore $(\mathrm{p}<.05)$ critical thinking scores for cohort 2 and cohort 3. Tables 5, 6, and 7 contain the Bonferroni comparisons used to identify these statistically significant different critical thinking artifact scores in each of the three cohorts. 
Table 5. Bonferroni Comparison of Critical Thinking Scores in Cohort 1

\begin{tabular}{lccc|cr}
\hline \multicolumn{1}{c}{ Comparisons } & $\begin{array}{c}\text { Mean Score } \\
\text { Difference }\end{array}$ & Std. Error & Sig. & Lower Bound & Upper Bound \\
\cline { 3 - 6 } & .553 & .152 & .004 & .133 & .973 \\
Senior vs. Freshman & .527 & .135 & .002 & .152 & .901 \\
Senior vs. Sophomore & .318 & .140 & .169 & -.069 & .706 \\
Senior vs. Junior & .235 & .147 & .707 & -.172 & .641 \\
Junior vs. Freshman & .208 & .113 & .435 & -.105 & .521 \\
Junior vs. Sophomore & .026 & .147 & 1.00 & -.380 & .433 \\
Sophomore vs. Freshman & & & & & \\
\hline
\end{tabular}

Table 6. Bonferroni Comparison of Critical Thinking Scores in Cohort 2

\begin{tabular}{lccc|cr}
\hline \multicolumn{1}{c}{ Comparisons } & $\begin{array}{c}\text { Mean Score } \\
\text { Difference }\end{array}$ & Std. Error & Sig. & Lower Bound & Upper Bound \\
\cline { 4 - 6 } & .558 & .113 & .000 & .249 & $.85 \%$ \\
Senior vs. Freshman & .588 & .102 & .000 & .280 & .837 \\
Senior vs. Sophomore & -.035 & .112 & 1.00 & -.340 & .269 \\
Senior vs. Junior & .593 & .108 & .000 & .298 & .887 \\
Junior vs. Freshman & .594 & .098 & .000 & .326 & .861 \\
Junior vs. Sophomore & -.001 & .092 & 1.00 & -.253 & .252 \\
Sophomore vs. Freshman & & & & & \\
\hline
\end{tabular}

Table 7. Bonferroni Comparison of Critical Thinking Scores in Cohort 3

\begin{tabular}{lccc|cr}
\hline \multicolumn{1}{c}{ Comparisons } & $\begin{array}{c}\text { Mean Score } \\
\text { Difference }\end{array}$ & Std. Error & Sig. & Lower Bound & Upper Bound \\
\cline { 4 - 6 } & .560 & .091 & .000 & .312 & .807 \\
Senior vs. Freshman & .598 & .099 & .000 & .329 & .866 \\
Senior vs. Sophomore & .076 & .110 & 1.00 & -.222 & .374 \\
Senior vs. Junior & .483 & .094 & .000 & .227 & .739 \\
Junior vs. Freshman & .521 & .100 & .000 & .249 & .794 \\
Junior vs. Sophomore & -.038 & .091 & 1.00 & -.286 & .210 \\
Sophomore vs. Freshman & & & & & \\
\hline
\end{tabular}

\section{DISCUSSION}

The significant increase in critical thinking scores over the four years supported the research hypothesis. Although there is not a baseline cohort for comparison who did not receive explicit critical thinking instruction, the increase in critical thinking scores is an encouraging finding for the engineering profession and public who need engineers who can think critically. Some may challenge tracking critical thinking assessment using specific course content due to the fact that the artifact rated is different in each course, as opposed to implementing a uniform critical thinking test, although one study attests to the superiority of assessing specific course content (Renaud \& Murray, 2008). The approach can be further justified by the literature since it supplied exposure and discussion in many contexts, each artifact was a written analysis of some type of problem-solving, and the assignments placed a continued emphasis on critical thinking as a needed meta-cognitive skill, all of which have been cited as important in critical thinking skill development (Bailin, Case, Coombs \& Daniels, 1999), (Tsui, 2000, 2002), Cooney et al. (2008). The participating faculty shared with the study authors that their intentional focus and emphasis on teaching critical thinking improved their teaching as they specifically emphasized meta- cognition to students. The faculty felt they encouraged purposeful, reasoned, and goal-directed thinking as discussed by Halpern (2003); that intentionally working with students to become meta-cognitive has value.

This study tracked only those students who stayed in-phase with their freshman year cohort. For example, if a student got out of sequence with some of the pre-requisites, they might take the sophomore course a different semester from the main semester tracked; or a student might go on cooperative internship in a semester off from their cohort. For this reason, as well as attrition from the engineering school in general, the numbers dropped from year one to year four for each cohort. However, as infusing critical thinking was new to the engineering school during this project and resources were scarce, key faculty teaching in-phase cohort courses were the only ones targeted for this study. 
The decrease from cohort 1 to cohorts 2 and 3 in the faculty rater average CT score is most likely the result of faculty gaining experience in scoring against a holistic rubric. It took faculty some time to learn to avoid norm referencing and to avoid trying to compensate for the age of the student. As faculty gained practice and experience scoring with the rubric, they became much more aware of the need for students to support their statements rather than accepting reasonable statements without proper justification. As faculty began to internalize the components of the framework, especially the use of the standards to assess the quality of the reasoning, they tended to give more low scores and fewer high scores. We also noticed that fatigue played a huge role in scoring consistency as did content-knowledge level of the rater. Faculty noted that distinguishing between 2's and 3's were often difficult. They expressed some preference for modifying the rubric for future projects.

Limitations of the study include the convenience sample, lack of a control group, study participant attrition, and use of an institution developed assessment rubric. The authors acknowledge the absence of a control group compromises the study design. However, the engineering program had already begun to implement critical thinking strategies as part of the university's quality enhancement plan for regional reaccreditation. To include a control group would have delayed the program's progression on implementation of the university-wide initiative.

\section{CONCLUSION/SUMMARY}

The longitudinal study provided an opportunity to encourage and support faculty in the intentional and transparent teaching of critical thinking, and demonstrated a positive impact on the development of students' critical thinking abilities. Faculty embraced the Paul-Elder framework and produced a holistic rubric for engineering based on the framework. Faculty raters continue to refine and enhance course critical thinking experiences. There are dedicated and sustained efforts in the school of engineering to embed in an intentional and systematic manner critical thinking instruction and assignments in core courses that align with the Paul-Elder critical thinking framework. This type of assessment strengthens and augments ongoing strategies that assess ABET outcomes, and this instruction and assessment should continue to improve the critical thinking skills of undergraduates which is considered highly important by college faculty, administrators and employers alike (Stein \& Haynes, 2011), (AAC\&U,2011), (Hart Research Study, 2013).

This model for developing assignments and assessing student responses fills a gap that is in the literature for engineering program assessment of critical thinking and can be duplicated in other disciplines interested in program assessment of critical thinking.

As a result of this longitudinal study, faculty in the engineering school have anecdotally reported placing more time and intentional emphasis on the teaching of critical thinking. Faculty had always demonstrated critical thinking, but with the introduction of the Paul-Elder critical thinking framework and collection of written artifacts that require an explanation of the thinking involved in problem solving, the undergraduates are getting a more focused, explicit, intentional emphasis on critical thinking that will be invaluable in their engineering practice. Data are being analyzed from a follow-up study that assessed the impact of this study on faculty participants, specifically the impact of the rating sessions and training on their teaching of critical thinking.

\section{ADDITIONAL PAPER INFORMATION}

This paper presents the final analysis and results of a six year longitudinal study that followed three cohorts of students through their undergraduate program. Initial discussion and preliminary results have been presented in previous papers by the authors (Ralston \& Bays, 2010; Ralston, Larson, \& Bays, 2011; Ralston \& Bays, 2013).

\section{AUTHOR INFORMATION}

Patricia A. S. Ralston, PhD (U. of Louisville, 1983) is Professor and Chair of the Department of Engineering Fundamentals. Dr. Ralston teaches undergraduate engineering mathematics and performs educational research on the effective use of technology in engineering education, the incorporation of critical thinking in undergraduate engineering education, and retention of engineering students. She leads a research group whose goal is to foster 
active interdisciplinary research which investigates learning and motivation to promote retention and student success in engineering. Her fields of technical expertise include process modeling, simulation, and control.

Cathy L. Bays, PhD, APRN, AGNP-C (U. of Cincinnati, 1995) is currently a nurse practitioner in the Department of Neurology with the University of Louisville Physicians group. During this research study she was the assessment specialist for the University of Louisville's regional reaccreditation initiative. She was an Associate Professor and Director of the School of Nursing's undergraduate program. Her areas of expertise and research interest are critical thinking assessment, creative teaching methodologies, and quality of life for stroke survivors.

\section{REFERENCES}

Association of American Colleges and Universities (2011). The LEAP vision for learning: Outcomes, practices, impact, and employers' view. Retrieved from the Association of American Colleges and Universities website: http://www.aacu.org/sites/default/files/files/LEAP/leap vision summary.pdf

ABET. (2013). Criteria for Accrediting Engineering Programs, Effective for Evaluations during 2014-2015 Accreditation Cycle. Retrieved from the ABET website: http://www.abet.org/eac-criteria-2014-2015/

AC Nielsen Research Services. (2000). Employer Satisfaction with Graduate Skills. Retrieved from a web archive: http://webarchive.nla.gov.au/gov/20120328194304/http://www.dest.gov.au/archive/highered/eippubs/eip99 -7/eip99_7pdf.pdf

Ahern, A., O'Connor, T.O., McRuairc, G., McNamara, M., \& O’Donnell, D. (2012). Critical thinking in the university curriculum-the impact on engineering education. European Journal of Engineering Education, $37(2), 125-132$.

Alfrey, K., \& Cooney, E. (2009, June). Developing a rubric to assess critical thinking in assignments with an openended component. Paper presented at the American Society for Engineering Education Annual Conference and Exposition, Austin, TX.

Bailey, J., (1979). The Effects of an Instructional Paradigm on the Development of Critical Thinking of College Students in an Introductory Botany Course. Dissertation Abstracts International 40(6): 3138A.

Bailin, S., Case, R., Coombs, J., \& Daniels, L. (1999). Common misconceptions of critical thinking. Journal of Curriculum Studies, 31(3), 269-283.

Bartko J.J. (1976). On various intraclass correlation reliability coefficients. Psychological Bulletin, 83, 762-765.

Bensley, D. \& Murtagh, M. (2012). Guidelines for a scientific approach to critical thinking assessment. Teaching of Psychology, 39, 5-16.

Berge, N. \& Flora, J. (2010, June). Engaging students in critical thinking: An environmental engineering effect. Paper presented at the American Society for Engineering Education National Conference and Exhibition, Louisville, KY.

Bloom, B.S. (1956). Taxonomy of educational objectives: The classification of educational goals. New York, NY: Longmans.

Bogo, M. and Vayda, E.J. (1998). The practice of field instruction in social work: Theory and process. Toronto, Canada: University of Toronto Press.

Brookfield, S. (1987). Developing critical thinkers: Challenging adults to explore alternative ways of thinking and acting. San Francisco, CA: Jossey-Bass.

Bruno, B. \& Anderson, A. (2005). Using objective driven heat transfer lab experiences to simultaneously teach critical thinking skills and technical content. Innovations in Engineering Education, 177-189.

Bumbaco, A. \& Douglas, E. (2014, June). A thematic analysis on critical thinking in engineering undergraduates. Paper presented at the American Society for Engineering Education National Conference and Exhibition, Indianapolis, IN.

Cavaliere, J. \& Mayer, B. (2012). Flooding the zone: A ten-point approach to assessing critical thinking as part of the AACSB accreditation process. Education, 133, 361-366.

Chang, P. \& Wang, D. (2011). Cultivating engineering ethics and critical thinking: a systematic and cross-cultural education approach using problem-based learning. European Journal of Engineering Education, 36(4), 377-390.

Claris, L. \& Riley, D. (2012). Situation critical: critical theory and critical thinking in engineering education. Engineering Studies, 4(2), 101-120.

Cooney, E., Alfrey, K., \& Owens, S. (2008, June). Critical thinking in engineering and technology education: A 
review. Paper presented at the American Society for Engineering Education National Conference and Exhibition, Pittsburg, PA.

Damron, R., \& High, K. (2008, October). Innovation in linking and thinking: critical thinking and writing skills of first-year engineering students in a learning community. Paper presented at the ASEE/IEEE Frontiers in Education Conference, Sarasota Springs, NY.

Douglas, E. P. (2012). Defining and measuring critical thinking in engineering. Procedia-Social and Behavioral Sciences, 56, 153-159.

Ennis, R. H. (1962). A concept of critical thinking, Harvard Educational Review, 32(1),81-111.

Eppes, T.A., Milanovic, I., \& Sweitzer. F. (2012). Towards liberal education assessment in engineering and technology programs. Journal of College Teaching and Learning, 9, 171-177.

Facione, N.C. and Facione, P.A. (1996). Externalizing the critical thinking in knowledge development and clinical judgment. Nursing Outlook, 44, 129-136.

Flores, K. L., Matkin, G. S., Burbach, M. E., Quinn, C. E. \& Harding, H. (2012). Deficient critical thinking skills among college graduates: implications for leadership. Educational Philosophy and Theory, 44(2). doi: 10.1111/j.1469-5812.2010.00672.x

Golter, P., Van Wie, B., Brown, G., Thiessen, D., Yurt, N., \& Abdul, B. (2009, June). Aligning assessment tools with course subject and goals. Paper presented at the American Society for Engineering Education National Conference and Exhibition, Austin, TX.

Gurmen, N., Lucas, J., Malmgren, D., \& Folger, H. (2003, June). Improving critical thinking and creative problem solving skills by interactive troubleshooting. Paper presented at the American Society for Engineering Education National Conference and Exhibition, Nashville, TN.

Hart Research Associates (2013). It Takes More Than A Major: Employer Priorities for College Learning and Student Success. Retrieved from The American Association of Colleges and Universities website: https://www.aacu.org/sites/default/files/files/LEAP/2013_EmployerSurvey.pdf

Halpern, D. F. (2003). Thought and knowledge: An introduction to critical thinking. Mahwah, NJ: Erlbaum.

Jiusto, S. \& DiBiasio, D. (2006). Experiential learning environments: Do they prepare our students to be selfdirected, life-long learners? Journal of Engineering Education, 95, 195-204.

$\mathrm{Ku}$, K.Y.L. (2009). Assessing students' critical thinking performance: Urging for measurements using multiresponse format. Thinking Skills and Creativity, 4, 70-76.

Liu, O. L., Frankel, L. \& Roohr, K. C. (2014). Assessing critical thinking in higher education: current state and directions for next-generation assessment. Educational Testing Service Research Report. ETS RR-14-10, DOI: $10.1002 /$ ets2.12009.

Lombardo, S. (2004). Using small blocks of time for active learning and critical thinking. Chemical Engineering Education, 38(2), 150-153.

Lunt, B., \& Helps, R. (2001, June). Problem solving in engineering technology: creativity, estimation and critical thinking are essential skills. Paper presented at the American Society for Engineering Education National Conference and Exhibition, Albuquerque, NM.

Mani, M., Omidvar, I., \& Knott, K. (2003, June). Learning to think critically to solve engineering problems: revisiting John Dewey's ideas for evaluating engineering education. Paper presented at the American Society for Engineering Education National Conference and Exhibition, Nashville, TN.

Mattingly, S., Weatherton, Y. P., Druzic, A. P., Frost, H.L. \& Rahman, Z. (2014, June). Critical thinking in the curriculum: making better decisions. Paper presented at the American Society for Engineering Education National Conference and Exhibition, Indianapolis, IN.

McKitrick, S. \& Barnes, S. (2012). Assessment of critical thinking: An evolutionary approach. Journal of Assessment and Institutional Effectiveness, 2, 1-29.

Nelson, S. (2001, October). Impact of technology on individuals and society: a critical thinking and lifelong learning class for engineering students. Paper presented at the Frontiers in Education Conference, Reno, NV.

Nosich, G.M. (2012). Learning to think things through: A guide to critical thinking across the curriculum. Upper Saddle River, NJ: Pearson Prentice Hall.

Papadopoulos, C., Rahman, A., \& Bostwick, J. (2006, June). Assessing critical thinking in mechanics in engineering education. Paper presented at the American Society for Engineering Education National Conference and Exhibition, Chicago, IL.

Paul, R., Elder, L., \& Bartell, T. (1996). Research findings and policy recommendations study of 38 public and 28 
private universities to determine faculty emphasis on critical thinking in instruction. Retrieved from The Critical Thinking Community website: http://www.criticalthinking.org/pages/study-of-38-publicuniversities-and-28-private-universities-to-determine-faculty-emphasis-on-critical-thinking-ininstruction $/ 598$

Paul, R \& Elder, L. (2001). Critical thinking: Tools for taking charge of your learning and your life. Upper Saddle River, NJ: Prentice Hall.

Paul, R. \& Elder, L. (2008). The Miniature Guide to Critical Thinking Concepts \& Tools. The Foundation for Critical Thinking.

Paul, R. \& Elder, L. (2009). Critical thinking: Concepts \& tools. Dillon Beach, CA: The Foundation for Critical Thinking.

Paul, R., Niewoehner, R. \& Elder, L. (2006). The Thinker's Guide to Engineering Reasoning. The Foundation for Critical Thinking.

Ralston, P. \& Bays, C. (2010, June). Refining a critical thinking rubric for engineering. Paper presented at the American Association for Engineering Education Annual Conference and Exhibition, Louisville, KY.

Ralston, P., Larson, A., \& Bays, C. (2011). An assessment of undergraduate engineering students' critical thinking skills guided by the Paul-Elder critical thinking framework. INQUIRY: Critical Thinking Across the Disciplines, 26(3), 25-32.

Ralston, P. \& Bays, C. (2013). Enhancing critical thinking across the undergraduate experience: An exemplar from engineering. American Journal of Engineering Education, 4(2), 119-126.

Renaud, R. D., \& Murray, H. G. (2008). A comparison of a subject-specific and a general measure of critical thinking. Thinking Skills and Creativity, 3, 85-93.

Rogers, G. (2006). Rubrics: What are they good for anyway? Community Matters, September, 3.

Scriven, M. \& Paul, R. (1987). Defining critical thinking. Retrieved from The Critical Thinking Community website: http://www.criticalthinking.org/pages/defining-critical-thinking/766

Shrout, P.E. \& Fleiss, J.L. (1979). Intraclass correlations: Uses in assessing rater reliability. Psychological Bulletin, $86,420-428$.

Sgro, S. \& Freeman, S. (2008, June). Teaching critical thinking using understanding by design curriculum development methods. Paper presented at the American Association for Engineering Education Annual Conference and Exhibition, Pittsburg, PA.

Shuman, L., Besterfield-Sacre, M. \& McGourty, J. (2005). The ABET "professional skills"-can they be taught? Can they be assessed? Journal of Engineering Education, 94, 41-55.

Stein, B. \& Haynes, A. (2011, March/April). Engaging faculty in the assessment and improvement of students' critical thinking using the CAT. Change, The Magazine of Higher Learning, 44-49.

Stevens D.D. and Levi, A. (2005). Introduction to rubrics: An assessment tool to save grading time, convey effective feedback and promote student learning. Sterling, VA: Stylus.

Swalie, B.H. \& Kreppel, M.C. (2001, June). Building critical thinking, teamwork, and communication skills through professional ethics in engineering and chemical technology. Paper presented at the American Association for Engineering Education Annual Conference and Exhibition, Albuquerque, NM.

Tsui, L. (1998, November). A review of research on critical thinking. Paper presented to the 23rd National Conference of the Association for the Study of Higher Education, Miami, FL. Retrieved from ERIC database: http://files.eric.ed.gov/fulltext/ED427572.pdf.

Tsui, L. (2000). Effects of campus culture on students' critical thinking. The Review of Higher Education, 23(4), 421-441.

Tsui, L. (2002). Fostering critical thinking through effective pedagogy: evidence from four institutional case studies. Journal of Higher Education, 73(6), 740-763.

Van Loon, J. E. \& Lai, H. L. (2014). Information literacy skills as a critical thinking framework in the undergraduate engineering curriculum. Library Scholarly Publications. Paper 80 http://digitalcommons.wayne.edu/libsp/80

Wolverton, R., \& Wolverton, J. (2003, June). Implementation of ethics education throughout an engineering college. Paper presented at the American Association for Engineering Education Annual Conference and Exhibition, Nashville, TN. 